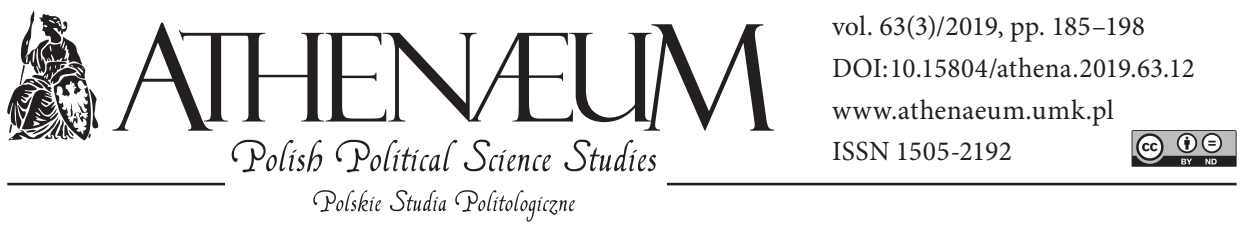

\title{
THE OBJECTIVES AND TASKS OF THE INTERNAL HISTORICAL POLITICS IMPOSED BY THE LAW AND JUSTICE PARTY IN THE YEARS 2005-2007
}

\author{
CELE I ZADANIA WEWNĘTRZNEJ POLITYKI HISTORYCZNEJ \\ PRAWA I SPRAWIEDLIWOŚCI W LATACH 2005-2007
}

\author{
Konrad Słowiński* 구
}

\begin{abstract}
The article deals with the issue of the internal historical politics of Law and Justice party (PiS) during their years of power in 2005-2007. From the very beginning, the party put an extreme importance to the issue of patriotism and national memory, making them one of their main objectives. With the inception of power in 2005 , the leaders of this group clearly declared that the important goal of their actions would be to restore historical memory, which was to be initiated by the "new historical politics". When analyzing the historical policy pursued by Law and Justice in the internal dimension, it should be noted that it focused on several key elements. The first of them was building patriotic attitudes among the Polish society. The historical settlement of the communist times became the second goal of the party's historical politics. The past has begun to be used by the leaders of this formation also to stigmatize political opponents. Moreover, it served as an effective tool to both
\end{abstract}

Artykuł podejmuje zagadnienie wewnętrznej polityki historycznej Prawa i Sprawiedliwości (PiS) w okresie sprawowania przez tę partię władzy w Polsce w latach 2005-2007. Już od samego początku swej działalności ugrupowanie to przywiązywało niezwykle istotną wagę do kwestii patriotyzmu i pamięci narodowej, czyniąc z nich jeden $\mathrm{z}$ głównych filarów swej polityki. $\mathrm{Z}$ chwilą objęcia władzy w 2005 r. jej przywódcy wyraźnie zadeklarowali, że ważnym celem ich działań stanie się przywrócenie pamięci historycznej, czemu służyć miało zainicjowanie „nowej polityki historycznej”. Analizując politykę historyczną prowadzoną przez PiS w wymiarze wewnętrznym, należy stwierdzić, że koncentrowała się ona na kilku zasadniczych elementach. Pierwszym z nich było budowanie wśród społeczeństwa postaw patriotycznych. Drugim celem polityki historycznej PiS stało się historyczne rozliczenie czasów komunistycznych. Przeszłość zaczęła być wykorzystywana przez liderów tej formacji także

* The John Paul II Catholic University of Lublin, Faculty of Social Sciences. 
Kaczyński brothers for mobilizing their own supporters.

Keywords: Historical politics; Law and Justice Party; Poland; political parties do piętnowania politycznych oponentów. Posłużyła ona także braciom Kaczyńskim jako skuteczne narzędzie mobilizacji własnych sympatyków.

Słowa kluczowe: polityka historyczna; Prawo i Sprawiedliwość; Polska; partie polityczne

\section{INTRODUCTION}

The issue of historical politics has recently raised the interest of the scholars in many scientific disciplines like history, political science, sociology, anthropology, pedagogy or culture studies. The issue has been broadly discussed in the public debate gaining the attention of the publicists. It has also become one of the main topics for the majority of the society. The very term "historical politics" has been used for the first time in Trewir (Geschichtspolitik) in 1986, during the German historians. From that moment on, it has been gaining popularity as the local scholars began to analyze the matter of the relationship between the history and the Germanpolitics. In Poland, the term has appeared recently and it is constantly gaining popularity.

Due to the fact that the "historical politics" has become of interest of many scholars from various backgrounds, it is very difficult to establish one definition for this term. A well-known researcher of the history of ideas, Marek Cichocki, who was one of the first to introduce this concept to the public debate in Poland, claimed that the historical politics is: "enhancing the public discourse about the past, both inside and outside the country, throughout the various forms of institutionalizing this discourse. Such institutionalizing occurs at the level of central and governmental institutions as well as at the level of regional ones" (Polityka historyczna - za i przeciw, 2006). The author also highlights the fact that conducting the historical politics should be seen as one of the governmental duties. Thus, engaging the governmental institution is crucial for creating the process as well as for passing on the historical knowledge (Cichocki, 2005b). On the other hand, Anna Wolff-Powęska defines the "historical politics" as the "political class conscious action which aims at shaping the extent and the character of the historical collective memory" (Wolff-Powęska, 2007). As the author notices, due to the various subjects influencing the way the society understands, systematizes and sees the past, the political influence over the interpretation of the past often leads to some quarrels and tension with others involved (institutions, organiza- 
tions, scholars). Thus, it is necessary to include such crucial factors as family, school, and local tradition. Simultaneously, according to the author, carrying out the historical politics requires a public legitimation (Wolff-Powęska, 2007). During the debate on this subject conducted within the Bulletin of the Institute of National Remembrance (Biuletyn Instytutu Pamięci Narodowej), Janusz Kurtyka described the historical politics as "certain actions which we undertake as a state to assimilate society with what we consider important" (Polska polityka historyczna, 2006). Furthermore, Kurtyka included an important message regarding how to shape "good" historical politics. According to him, historical politics should strive to "the huge space created by the independent research". This independence - as Kurtyka claimed - enabled the opportunity to carry out the scientific disputes, debates, and it pointed out the existence of various streams of historical reflection (Polska polityka historyczna, 2006). Furthermore, the concept has been differently described by Lech Nijakowski - although in this particular case the author uses the name "the politics of memory" - who sees it as "all intentional actions carried out by politicians and administration that aim at preservation, deletion and redefining the particular content within the national memory. These actions can be both of innovative character as well as routinized practices" (Nijakowski, 2006).

Taking under consideration the given views, it can be stated that currently there is no consistent definition that would enable to cover entire phenomenon. One of the attempts to conceptualize the said term was made by Anna Wójcik, who claimed that historical politics is "the category of history that serves to create the historical consciousness of society, in particular the awareness of territorial affiliation and the strengthening of the discourse over the past in order to nurture permanent national ties regardless of the current, changing state policy" (Wójcik, 2016).

\section{THE CONCEPT OF THE HISTORICAL POLITICS IN POLAND AFTER 1989}

As it was noticed by Antoni Dudek, two separate trends - liberal and conservative - have emerged in Poland after 1989 (Dudek, 2011). The former assumes full neutrality of the state in the sphere of social memory management. According to this concept, the state should not engage its institutions into this process accepting the total impartiality in this matter and focusing its attention primarily on 
other areas of activity (e.g., military, economic, foreign). In other words, according to the supporters of such attitude, it can become the tool for propaganda or indoctrination. The supporters of the liberal trend point out that promoting any historical values by the state can lead to creating the fake picture of the past that neglects the threads in opposition to the presented narration. Such imposition of a certain thinking direction - in their opinion - will result in a selective treatment of the memory of the past, which "will make it impossible to understand anything from our history" (Janowski, 2006).

Conservative attitude emphasizes the need for the state to actively engage in propagating patriotic attitudes, emphasizing the positive image of its history and cultivating the historical achievements of its own nation. According to the supporters of this idea, history (and historical memory) plays too great a role in a socio-political sphere to leave it to shape a free market game (Tokarz, 2011). As Marek Cichocki stated, "the memory needs to remain as a life substance of very politics" (Cichocki, 2005a). For this reason, the conservatives considered it necessary to involve state institutions in building active civic attitudes, promoting those threads from the history which could serve as reference points and formulas for contemporary Poles (Merta, 2005). In their opinion, the historical politics should be the tool for strengthening the national community. Thus, it was necessary to promote the modern patriotism and enhance the feeling of national pride, however, it could not exclude the omission of those issues from the past that would put the nation or its part in a bad light (Olszewski, 2013).

The collapse of the communist regime in Poland, which began at the turn of the $80^{\mathrm{s}}$ and $90^{\mathrm{s}}$ of the $20^{\text {th }}$ century, initiated a profound change in the political system in our country. During the process of transformation of political, cultural and social life that took place at that time, the dominant role towards the historical politics was played by the liberal trend (Dudek, 2011). Thus, the state adopted the principle of neutrality and impartiality in the sphere of social memory management. The famous electoral slogan of Aleksander Kwaśniewski "choose the future", that he threw during the presidential campaign in 1995, which symbolized the total désintéressement for the area, became a tangible testimony to this approach. Thus, the democratic order - according to liberal circles - had to be built without referring to the sphere of symbols, historical memory, that should be sacrificed for the sake of progress and modernization. 


\section{THE MAIN ELEMENTS OF THE INTERNAL HISTORICAL POLICY OF THE LAW AND JUSTICE PARTY}

From the very beginning, Law and Justice main goal was "to strengthen the independent existence of the Republic of Poland and the international position of Our Country" as well as "to spread the patriotic attitudes and enhancing social and national solidarity among the Poles" (Statut Prawa i Sprawiedliwości, 2006). This political party definitely rejected the liberal approach to historical politics, instead approaching the conservatives' position in this matter. For the members of Law and Justice, the matters related to patriotism, national memory, constituted one of the key elements of maintaining the national cohesion of the Polish society, raising the level of civilization and the quality of life of the Poles. Therefore, the subject of historical policy has found a fairly strong reflection in the statutes and programs of this party. What is more, the members of the party often give a lot of space to the matter in their political speeches. Already in one of the first program conventions from 2001, the leaders of this party pointed out that "the center of our thinking and political feeling occurs within the nation, as a community of history, a community of culture" (Naprawa polskiego państwa..., 2001). Defining a nation in such categories indicates a huge role that Law and Justice members ascribed in their politics to the issue of remembrance, past and national identity. As it was mentioned by Kazimierz Ujazdowski: "our life needs to be unambiguously embedded in the tradition of the First Polish Republic, the fight for independence during the partitions, the struggle against German and Soviet occupants during World War II, as well as in the tradition of struggle against the communist regimes in Poland" (Naprawa polskiego państwa..., 2001). According to the party leaders, without a strong moral and historical legitimation, the state cannot function and fulfill its role well.

Joining the elections in 2005, the party leaders clearly declared that one of their main objectives would be to restore historical memory. The implementation of the task was initiated by introducing the "new historical policy" which assumed a strong activation of the state in this particular sphere. Before the Polish governmental campaign, Jarosław Kaczyński declared the need to undertake vigorous actions in the field of historical politics, which should be directed to both external and internal recipients. The importance of the matter is highlighted by the fact that in the amendment of the constitution proposed by the party, this topic was to play an extremely important role: "It is very important in this constitution to clearly define the historical identity [...] it is necessary to confirm 
the identity that clearly refers to the independence tradition, to the First and Second Polish Republic. At the same time, the identity [...] should be clearly anti-communist" (Wykład Prezesa Jarosława Kaczyńskiego..., 2005).

In their electoral program named IV Rzeczpospolita. Sprawiedliwość dla wszystkich, Law and Justice gave unambiguous signal of the renascent Polish historical politics: "We will conduct deliberate historical politics, both the internal and external one. The internal historical policy assumes constant care about the quality of historical education at schools and in the media, as well as constant efforts to not only commemorate the history of our state and nation, but also to maintain their lively presence in the minds of citizens. It is crucial to support research programs and educational projects disseminating knowledge about our past, as well as any institutions documenting and popularizing history" (IV Rzeczpospolita. Sprawiedliwość dla wszystkich..., 2005). Historical politics has become one of the flagship objectives for this party. For their supporters, it aimed at serving as the foundation of modern politics. It was highlighted by both Prime Ministers - Kazimierz Marcinkiewicz as well as Jarosław Kaczyński.

As it was pointed out by Joanna Sanecka, the Law and Justice historical politics, carried out in the internal aspect (concerning its role in establishing the national education and creating the identity) focuses on three prime elements: 1 ) the development of the historical-patriotic education in schools, shaping the civic and pro-state attitudes, instilling a sense of national dignity, 2) rebuilding the national community, and 3) strengthening the state by firmly embedding it in the national tradition (Sanecka, 2008). One additional point should also be added to this list. It was a historical account of the times of the regime, "showing what was the essence of communism and the Polish People's Republic" (IV Rzeczpospolita. Sprawiedliwość dla wszystkich..., 2005). The realization of these goals was to be undertaken by a number of initiatives whose implementations were announced by the activists of this party. The most important ones include plans for creating the Museum of Polish History as well as the Museum of the History of Polish Jews (POLIN), the Józef Piłsudski and the Second Polish Republic Museum in Sulejówek, the Museum of Freedom and Solidarity in Bydgoszcz, the Museum of Westerplatte in Gdańsk, as well as the Museum of Western Territories in Wrocław.

At that time, the key role was ascribed to the creation of the Museum of Polish History, which, according to the Law and Justice activists, was believed to become the most significant element of the "new historical politics". As is was pointed out by Kazimierz Ujazdowski, "our main project is to establish the Museum of Polish History, a place that is going to be a modern institution show- 
ing our entire historical experience in a communicative way since Poland [...] should have institutions that continuously show the uniqueness of our historical experience and the contribution of Poland in the history of Europe and the world" (Kazimierz Ujazdowski..., 2006). The decision of establishing the Museum was made in 2006 but its opening, due to the lack of permanent financing, was postponed to the next years ${ }^{1}$. The main objective of the Museum is to show the main threads of the Polish history - both the state and the nation - concentrating mainly on the subject of freedom, i.e., parliamentary traditions, institutions and civic movements, and the fight for freedom and independence. According to its originators, it should shape a modern patriotic sensitivity, contribute to shaping the society that is aware of its traditions and open to the world. Furthermore, another important aspect of it is also to build the international picture of Poland actively, so that Polish history and culture are understandable and attractive to foreigners. Jarosław Kaczyński confirmed how important the project is for all the Law and Justice activists saying that: "The Museum of Polish History will be built - a powerful institution that will influence the Polish national awareness in the future" (Premier podsumowat prace rzadu, 2007). It can be assumed that the main aim of this place - according to the party leaders - was to play an equally great role in shaping the Poles' national identity as the Warsaw Uprising Museum.

Another important element of the party's active historical politics is the establishment of the Museum of Freedom and Solidarity. The need of establishing such a place was highlighted long before the election campaign as the leaders pointed out the necessity of organizing "modern museum - educational and research institution, presenting the history of Poland (especially the twentieth century) through the idea of freedom which is so crucial for contemporary Poles" (Apel o polska polityke historyczna, 2004). The Museum of Freedom and Solidarity was established in 2006. Its aim was to display historical memorabilia, present archives, documentary films and works of art related to the activities of the opposition movements in Poland during the $1970^{\mathrm{s}}$ and $1980 \mathrm{~s}^{2}$.

The Law and Justice leaders, as part of their historical politics, have also been actively engaged in the construction of the Museum of the History of Polish Jews, that was established in January 2005, actively supporting the establishment of

1 Currently, the Museum is planned to be opened in 2020. It is going to be situated in Cytadela Warszawska, which is situated near the future headquarters of the Polish Army Museum.

2 Due to financial and housing issues, the institution was closed after 4 years of its activity. Currently, there are initiatives to reactivate the Museum. 
this institution. The necessity of creating such a place was highlighted by the then President of Warsaw - Lech Kaczyński, who saw it as one of the major challenges that the capital authorities must be faced with (Warszawo, daj się lubić, 2003). During the solemn establishment of the foundation act in 2007, he pointed out that "The history of Polish Jews is part of the history of my country, part of the history of my nation, which requires remembrance and commemoration" (Prezydent podpisał akt erekcyjny..., 2007). Additionally, as he pointed out, "This museum is a great opportunity to overcome the mutual lack of knowledge about each other and the chance for deeper and deeper reconciliations" (Prezydent podpisat akt erekcyjny..., 2007). The Museum was established to commemorate the long tradition of the Polish Jews and to rise the young generation in a spirit of mutual tolerance and respect for the Jewish culture. As it was emphasized by the Law and Justice representatives, it was seen as an element of creating good relations with both Israel and the Jewish diaspora around the world. As it was highlighted by the party leaders, "in Israel, there are some false stereotypes about Poland and these are really very unfavorable for us. I am referring to the alleged co-responsibility for the Holocaust. Such stereotypes are not only false, but simply deadly from the point of view of the interests of our state" (W Izraelu czuje sie jak $w$ domu, 2008). According to the leaders of Law and Justice, the Museum could be a kind of a bridge that can help to build a better relationship between the two sides by referring to the common tradition of co-existence of the two nations (Przesłanie Prezydenta RP..., 2006).

One of the main points in the internal historical politics by Law and Justice has been the question of the patriotic education and upbringing of young Poles. In fact, according to the leaders, the education of young people leads to a crisis in the sense of national identity of our society and weakens its cohesion. They think that it is crucial to 1) develop the quality of the historical education, 2) setting the programs for patriotic education in schools. The first step in improving the quality of historical education was to introduce a consistent concept of historical knowledge in schools as it was listed within the election program from 2001. This would make it possible to familiarize the student with "the basic canon of national culture and knowledge about the history of the country" as well as "elementary knowledge in the field of universal history, especially the European one" (Program Prawa i Sprawiedliwości, 2001). Secondly, this could have been achieved by increasing the hours of history teaching in schools. According to the leaders, the dissemination of historical knowledge was an important element of the civic education. The Law and Justice activists believed that the current role 
of school was limited only to the practical preparation of young people to live in the realities of the market economy. They claimed that: "Every student finishing school must have a basic knowledge of the history and culture of our country that allows him to function as a mature Pole who is fully aware of his identity" (Apel o polska politykę historyczna, 2004). The Law and Justice task was also to introduce the patriotic education in schools in order to shape the national community. As they highlighted: "The school educational program of must include a specially dedicated part of the patriotic education program. This program's elements must involve conducting relevant subjects in Polish language and the history of extra-curricular activities, celebrating national and local patron and school holidays, as well as the participation in external patriotic celebrations" (Apel o polska politykę historyczna, 2004). In this context, the actions of this party that postulate the position of a greater emphasis on the development of historical education may be considered as right. However, concretizing this idea, especially with regard to the idea of creating a consistent concept of historical knowledge, may be seen as doubtful. As a result, we may get the creation of a false image of the past that omits threads that are incompatible with the existing narrative.

The next matter undertaken by the Law and Justice in the field of internal historical politics was to support programs, institutions and associations whose aim was to popularize Polish history and culture. As it was declared by the members of the party, "The state should initiate and support the educational and social programs that are implemented jointly with non-governmental organizations pursuing educational goals (scouts, veterans, youth, student, educational and other organizations)" (Apel o polska politykę historyczna, 2004). The key role here was ascribed to the National Centre for Culture. According to its statute, it was to deal with maintaining and popularizing national and state tradition, promoting Polish national heritage, cultural education or inspiring and supporting social movements and non-governmental organizations functioning in the sphere of culture and national heritage. The Centre initiated many research programs, such as the "Patriotism of Tomorrow" program, consisting in supporting valuable educational, or educational and artistic initiatives which promote patriotic attitudes and tell about the Polish history in an interesting way. Another, no less interesting, project implemented by the Center was the program "Witnesses of History", aimed at collecting the accounts of forgotten heroes of the twentieth century and memories of the participants, or even observers of important events from World War II and the Polish People's Republic and archiving them on websites. What is important, under the Centre's auspices, “The Memory and 
the Future" institution has been established. It deals with the presentation of the after war history and the cultural heritage of the Poles from the western parts of the country. Kazimierz Ujazdowski highlighted that "The Polish success at the western lands should be one of the showcases that we can present to the world. Establishing in Wrocław 'The Memory and the Future' Centre means creating the institutional conditions for presenting the Polish civilizational and cultural heritage of these lands. The main tasks of this institutions are narrative exhibitions, educational activities, systematic documentary works" (Powołanie ośrodka "Pamięć i Przyszłośćc, 2007). An important mission of the institutions was also undertaking initiatives aimed at creating the Museum of Western Territories ${ }^{3}$.

The issue of the historical settlement of the times of the Polish People's Republic was of great importance in the internal historical policy of the Law and Justice party. The implementation of this objective was President Lech Kaczyński’s policy of honors, whose goal was to honor "silent heroes" - people who rendered merit to the Polish freedom and independence and were so far ignored by the state authorities (Jarzynka, 2015). The awards were given to those involved in the fight for independence immediately after World War II, to the participants in social protests in the Polish People's Republic, and those active in the anti-communist movement of the $1970^{\text {s }}$ and 1980s. Lech Kaczyński's activities aiming at honoring the Solidarity people should be especially brought to attention. The President called them the "third conspiracy". Thus, the Solidarity was given a special character of the symbol added to the pantheon of other important events in the last 100 years of our nation's history: "The history does not know many examples - maybe apart from 'Solidarity' it does not know any at all - when almost entire society organized itself against the totalitarian regime. It was the 'Solidarity' that was this organized movement during the years 1980-1981. After martial law, it became a large underground organization" (Kaczyński, 2007). It is worth mentioning that another great success of Lech Kaczyński was honoring all those people who after 1989 were often forgotten and often pushed to the margins of political and social life, and introduce them to the official state memory about the $U_{\text {Union }}^{4}$. In his internal historical politics, Kaczyński also awarded many others, so far neglected by the government, anti-communist oppositional activists as well as

3 The official opening of the Depot History Centre took place in 2016.

4 In 2006, the most important Polish distinction - the Order of the White Eagle - was given to Andrzej Gwiazda and Anna Walentynowicz. Apart from them, other members of the "Solidarity" were honored with different kind of distinctions by Lech Kaczyński. 
the participants of strikes and civic protests in the Polish People's Republic. The special place in Lech Kaczyński’s "award policy" occupied the participants of the Polish independence underground after the Second World War, whose activities he called the "second conspiracy" (Chmielecki, 2017).

The subject of the historical politics played an important role for the Law and Justice party. The Kaczyński brothers ${ }^{5}$ thought that it is an important element of citizens' consolidation, maintaining the national identity and building patriotism. In this respect, it should be considered legitimate to say that for its leaders, it is not enough to just run market mechanisms to create an efficiently functioning state. This view was expressed in the Law and Justice program declaration: "The state can not only limit itself to the economic functions, acting as a limited liability company. In the face of the weakness of contemporary authorities and the crisis of confidence in political solutions, it is worth referring to a wider perspective that allows one to see more and better, allows to see sense in places where current disputes make it blurred" (Apel o polska politykę historyczna, 2004). One need to agree with the view of the Law and Justice leaders that after the period of the political transformation, the subject of the historical identity and collective memory were thrown out of the public sphere. Meanwhile, as it was noticed by Dariusz Gawin, the issues related to shaping the collective memory of society, scientific conflicts regarding the interpretation of the past, using historical arguments in current international disputes require the necessity of discussing the historical policy (Gawin, 2005). What is also crucial, according to the leaders, this should not be seen as an unnecessary burden, which needs be rejected for the sake of progress and modernization. According to Lech Kaczyński: "[...] there is no contradiction between the fact that we want to have a certain historical policy (which, when rooted in the state, it strengthens its internal structure, otherwise it is built somewhat on the sands) and look into the future. Of course, the main task of the politicians, not only the President, is related to the future, not to the past, since there is nothing one can do about the past. However, there is still a need to talk about the past, refer to certain tradition that is right and to try to root our state in some tradition, which in the first dozen or so years did not exist in the

5 Under the term "Kaczyński brothers", the author understands the broader subjectivity of the Law and Justice political environment in which an important role was played by Lech Kaczyński. Although during his presidency he was no longer a member of the formation, however, together with Jarosław Kaczyński, he was one of the main creators of the "historical politics" carried out by the party. 
Third Polish Republic, as it was, but not to such extent" (Wywiad $z$ kandydatem na Prezydenta RP..., 2005).

\section{CONCLUSIONS}

The politics pursued by the Law and Justice party was limited in its internal dimension to the several key tasks. The first one was spreading of the patriotic attitudes, building a sense of community on the basis of family and the spirit of social solidarity, dissemination of national, patriotic and state traditions, popularizing the history of our country. According to the members of this party, Polish society was going through a crisis of national identity: "[...] and nothing has been done in terms of independence attitude and to prevent another, even more deeply embedded and dangerous phenomenon, which is the crisis of Polonism - the attitude of rejecting, or at least being deeply skeptical, about the values associated with the Polish nationality" (Kongres założcielski Prawa i Sprawiedliwości, 2001). According to Law and Justice, this leads to the weakening of cohesion of the Polish society and to putting its own interests over public good. The second objective of the historical politics of the party was to reckon the communism: "[...] unraveling the next elements of contemporary history, telling the truth about times of the Polish People's Republic and the martial law" (Spotkanie $z$ historia bez fatszu, 2005). This process was accompanied by the actions taken in the field of lustration and de-communization. At the same time, the history in this case has become the element of the political game oriented at pillorying the political opponents of the post-communist origins: "We will reveal the mechanisms of entanglement and continuation in SLD - very few already remember that the successor to the PZPR and at the same time the SLD predecessor, i.e., SdRP, was against our membership in NATO" (IV Rzeczpospolita. Sprawiedliwość dla wszystkich..., 2005). Here the first aspect of the historical politics occurs. This is the one that plays the crucial role not only as a mean of strengthening the national identity but also as a good tool for their supporters' mobilization. On the one hand, it served to build ties between the supporters of this party, creating a common identification based on the reference to the idea of patriotism and a sense of national pride. On the other hand, it was an instrument used for ongoing political struggle, an example of which was seen during the 2005 Presidential campaign when Jacek Kurski addressed Donald Tusk on concealing the fact about the service of his grandfather in Wehrmacht, 
that was to serve as an argument which accused Tusk of having pro-German views. The Law and Justice leaders used the past to attack the political opponents. The Kaczyński brothers described their party as a continuator of the ideas and views of the great figures of our history (Piłsudski, Dmowski) and referred to the tradition of heroic deeds and fights of the Poles, and saw the critics of their party as the heirs of the communist past ("departmental children", in Polish: resortowe dzieci). These actions show a certain dissonance between the noble goals of historical politics proclaimed by the leaders of Law and Justice, which was the patriotism resurrection and bringing the national pride back, and using it to the contemporary political fights.

\section{REFERENCES:}

Apel o polska politykę historyczna (2004). Retrieved from: http://old.pis.org.pl/article. php?id=3093.

Chmielecki, A. (2017). Polityka historyczna prezydenta Lecha Kaczyńskiego. Biuletyn Instytutu Pamięci Narodowej, 4, 99-107.

Cichocki, M. (2005a). Czas silnych tożsamości. In: A. Panecka (ed.). Polityka historyczna. Historycy - politycy - prasa (pp. 15-21). Warszawa: Muzeum Powstania Warszawskiego.

Cichocki, M. (2005b). Władza i pamięć. O politycznej funkcji historii. Kraków: Ośrodek Myśli Politycznej, Wyższa Szkoła Europejska im. księdza Józefa Tischnera.

Dudek, A. (2011). Historia i polityka w Polsce po 1989 roku. In: P. Skibiński, T. Wiścicki, \& M. Wysocki (ed.). Historycy i politycy. Polityka pamięci w III RP (pp. 33-57). Warszawa: Wydawnictwo DiG.

Gawin, D. (2005). Polityka historyczna i demokratyczne państwo. In: A. Panecka (ed.). Polityka historyczna. Historycy - politycy - prasa (pp. 22-27). Warszawa: Muzeum Powstania Warszawskiego.

IV Rzeczpospolita. Sprawiedliwość dla wszystkich. Prawo i Sprawiedliwość. Program (2005).

Janowski, M. (2006). Narodowa megalomania i jej manifestacje. Przeglad Polityczny, $78,64-69$.

Jarzynka, T. (2015). Koncepcja państwa w ujęciu Lecha Kaczyńskiego. Lublin: MW Press. Kaczyński, L. (2007). Przemówienie podczas uroczystych obchodów podpisania Porozumień Sierpniowych. Gdańsk, 31 VIII 2006 r. In: K. Janaszek, \& A. Fijewski (eds.). Wystapienia, listy, wywiady. Wybór (pp. 88-89). Warszawa: Kancelaria Prezydenta RP.

Kazimierz Ujazdowski w „Poranku Radia TOK FM”(2006). Retrieved from: http://old. pis.org.pl/article.php?id=4199\&st=2.

Kongres założycielski Prawa i Sprawiedliwości (2001). Falenty, December 1-2. 
Naprawa polskiego państwa - to jeden z głównych elementów programowych Prawa i Sprawiedliwości (2001). Retrieved from: http://old.pis.org.pl/article.php?id=1308.

Nijakowski, L. (2006). Baron Münchhausen, czyli o polskiej polityce pamięci. Przegląd Polityczny, 75, 54-62.

Olszewski, E. (2013). Pamięć społeczna i polityka historyczna w programach polskich partii politycznych. Środkowoeuropejskie Studia Polityczne, 2, 67-97. DOI: 10.14746/ ssp.2013.2.05.

Polityka historyczna - za i przeciw [Discussion by P. Dukielski, M. Cichocki, M. Kula, A. Werner, \& K. Mazur] (2006). Mówią Wieki, 8, 10-17.

Polska polityka historyczna (2006). Biuletyn Instytutu Pamięci Narodowej, 5, 2-33.

Powołanie ośrodka „Pamięć i Przyszłość" (2007). Retrieved from: http://old.pis.org.pl/ article.php?id=6564.

Premier podsumowat prace rządu (2007). Retrieved from: http://old.pis.org.pl/article. php?id=6337\&st $=5$.

Prezydent podpisał akt erekcyjny pod Muzeum Historii Żydów Polskich (2007). Retrieved from: http://old.pis.org.pl/article.php?id=8297.

Program Prawa i Sprawiedliwości (2001). Warszawa.

Przesłanie Prezydenta RP z okazji 60. rocznicy wydarzeń kieleckich (2006). Retrieved from: http://old.pis.org.pl/article.php?id=4439.

Sanecka, J. (2008). Polityka historyczna partii Prawo i Sprawiedliwość: założenia i realizacja. Athenaeum. Polish Political Science Studies, 19, 54-66.

Spotkanie z historią bez fałszu (2005). Rzeczpospolita, September 17.

Statut Prawa i Sprawiedliwości (2006). Retrieved from: http://old.pis.org.pl/bip/index. php? page $=$ doc\&id $=1$.

Tokarz, T. (2011). Koncepcja „polityki historycznej” w myśli konserwatystów polskich. Kultura i Historia, 19. Retrieved from: https://www.kulturaihistoria.umcs.lublin. $\mathrm{pl} /$ archives/2468.

Warszawo, daj się lubić! (2003). Rzeczpospolita, December 31.

W Izraelu czuję się jak w domu (2008). Rzeczpospolita, May 17.

Wolff-Powęska, A. (2007). Polskie spory o historię i pamięć. Polityka historyczna. Przegląd Zachodni, 63(1), 3-44.

Wójcik, A. (2016). Polityka historyczna jako forma budowy wizerunku Polski na arenie międzynarodowej. Świat Idei i Polityki, 15, 438-451.

Wykład Prezesa Jarosława Kaczyńskiego w Fundacji im. S. Batorego - „O naprawie Rzeczypospolitej" (2005). Retrieved from: http://old.pis.org.pl/article.php?id=270\&st=1. Wywiad z kandydatem na Prezydenta RP prof. Lechem Kaczyńskim w „Sygnałach dnia” (2005). Retrieved from: http://old.pis.org.pl/article.php?id=133. 